\title{
An In Vitro Study of the Photodynamic Effectiveness of GO-Ag Nanocomposites against Human Breast Cancer Cells
}

\author{
Fozia Shaheen ${ }^{1}$, Muhammad Hammad Aziz ${ }^{2, *}$, Muhammad Fakhar-e-Alam ${ }^{3,4}$, \\ Muhammad Atif ${ }^{5,6}$, Mahvish Fatima ${ }^{7}$, Riaz Ahmad ${ }^{8, *}$, Atif Hanif ${ }^{9}$, Saqib Anwar 10 (i), \\ Fatima Zafar ${ }^{11}$, Ghazanfar Abbas ${ }^{2}$, Syed Mansoor Ali ${ }^{5}$ and Mukhtar Ahmed ${ }^{2}$ \\ 1 Department of Physics, Government College (GC) University, Lahore 54000, Pakistan; \\ scarletfozia@yahoo.co.in or foziashaheen@gcu.edu.pk \\ 2 Department of Physics, COMSATS Institute of Information and Technology, Lahore 54000, Pakistan; \\ drghazanfarabbas@ciitlahore.edu.pk (G.A.); mukhtarahmad@ciitlahore.edu.pk (M.A.) \\ 3 Department of Physics, Government College (GC) University, Faisalabad 38000, Pakistan; \\ fakharphy@gmail.com \\ 4 Institute of Fundamental and Frontier Science, University of Electronic Science and Technology of China, \\ Chengdu 610054, China \\ 5 Department of Physics and Astronomy, College of Science, King Saud University, \\ Riyadh 11451, Saudi Arabia; atifhull@gmail.com (M.A.); mansoor_phys@yahoo.com (S.M.A.) \\ 6 National Institute of Laser and Optronics, Nilore 45650, Islamabad \\ 7 Department of Physics, University of Lahore, Lahore 54000, Pakistan; mahvish.fatima@phys.uol.edu.pk \\ 8 The Centre for Advanced Studies in Physics (CASP), Government College (GC) University, Church Road, \\ Lahore 54000, Pakistan \\ 9 Botany and Microbiology Department, Faculty of Science, King Saud University, \\ Riyadh 11451, Saudi Arabia; ahchaudhry@ksu.edu.sa \\ 10 Industrial Engineering Department, College of Engineering, King Saud University, P.O. Box 800, \\ Riyadh 11421, Saudi Arabia; sanwar@ksu.edu.sa \\ 11 Department of Chemistry, GC University, Lahore 54000, Pakistan; fatimazafar09@gmail.com \\ * Correspondence: hammadaziz@ciitlahore.edu.pk (M.H.A.); ahriaz@gcu.edu.pk (R.A.)
}

Received: 18 August 2017; Accepted: 4 October 2017; Published: 21 November 2017

\begin{abstract}
Graphene-based materials have garnered significant attention because of their versatile bioapplications and extraordinary properties. Graphene oxide (GO) is an extremely oxidized form of graphene accompanied by the functional groups of oxygen on its surface. GO is an outstanding platform on which to pacify silver nanoparticles (Ag NPs), which gives rise to the graphene oxide-silver nanoparticle (GO-Ag) nanocomposite. In this experimental study, the toxicity of graphene oxide-silver (GO-Ag) nanocomposites was assessed in an in vitro human breast cancer model to optimize the parameters of photodynamic therapy. GO-Ag was prepared using the hydrothermal method, and characterization was done by X-ray diffraction, field-emission scanning electron microscope (FE-SEM), transmission Electron Microscopy (TEM), energy dispersive X-rays Analysis (EDAX), atomic force microscopy and ultraviolet-visible spectroscopy. The experiments were done both with laser exposure, as well as in darkness, to examine the phototoxicity and cytotoxicity of the nanocomposites. The cytotoxicity of the GO-Ag was confirmed via a methyl-thiazole-tetrazolium (MTT) assay and intracellular reactive oxygen species production analysis. The phototoxic effect explored the dose-dependent decrease in the cell viability, as well as provoked cell death via apoptosis. An enormously significant escalation of ${ }^{1} \mathrm{O}_{2}$ in the samples when exposed to daylight was perceived. Statistical analysis was performed on the experimental results to confirm the worth and clarity of the results, with $p$-values $<0.05$ selected as significant. These outcomes suggest that GO-Ag nanocomposites could serve as potential candidates for targeted breast cancer therapy.
\end{abstract}


Keywords: graphene oxide (GO); photodynamic therapy; cytotoxicity; biocompatibility; reactive oxygen species (ROS)

\section{Introduction}

Graphene has been making a noteworthy effect and shows the potential application in biomedicine, for instance anticancer, antibacterial activity, cell science and bio-distinguishing and likewise showing drug conveyance limits [1-5]. Graphene has fantastic properties including a high electrical and thermal conductivity, surface area and mechanical properties. Graphene oxide (GO) nanosheets can be utilized as nanocarriers for drug delivery and intracellular fluorescent nanoprobe $[2,4,5]$. Subsequent advancement of covalently- and noncovalently-functionalized graphene-based materials enhanced their cytotoxicity and diminished their toxicity in the physiological environment [6]. The strong penetration capabilities of graphene-based nanocomposites make them able to produce trivial adverse effects on different cellular models, describing the importance of these nanocomposites for the studies of biological effects [7-11].

Graphene also signifies an esteemed platform for the progress of nanocomposites, permitting the transformation of nanomaterials with diverse properties to contribute to innovative materials with enriched or advanced functionalities. Graphene toxicity has been measured by numerous research groups owing to its divergent physicochemical features such as purity, the size of the sheets and the oxidation state, which may affect its cellular uptake and biodegradation [12,13]. However, graphene can spontaneously enter the plasma membrane, and it can be easily localized in the cytosol, synchronizing with cellular organelles. Graphene produces an increase of oxidative stress and metabolic activity related to the repairing mechanisms inside cells [12-14].

GO is the most common member of the graphene family in the study of in vitro toxicity $[10,11]$. Previous studies showed that at a lower concentration, treatment with GO in a human neuroblastoma SH-SY5Y cell line caused no significant cytotoxicity. Graphene oxide produced considerable cytotoxicity with continuous exposure to the SH-SY5Y cell line at a higher concentration for time duration of $96 \mathrm{~h}$ [15]. Yang et al. reported their work on mice and showed the potential toxicity of nanographene sheets with polyethylene glycol after injection in mice [16]. GO has the ability to adsorb protein, such that it can yield concentration-dependent cytotoxicity, which may possibly be lessened by incubation with $10 \%$ fetal bovine serum (FBS), owing to GO's enormously high protein adsorption ability [17].

Until now, metal nanostructures $(\mathrm{Ag}, \mathrm{Ni}, \mathrm{Au}, \mathrm{Cu})$ have received more attention in the medical field due to their impending influence on the environment and human health [18-20]. Silver nanoparticles (Ag NPs) play the vital role of a biocidal agent, and their toxicity phenomena are associated with oxidative stress and cell membrane damage $[18,21]$. Furthermore, silver dysregulates the mitochondrial respiratory system and decreases the effectiveness of antioxidant enzymes, such as glutathione transferases, causing the reduction of free radicals. Silver nanoparticles' toxicity may also be related to other mechanisms, such as the inhibition of DNA synthesis, actin depolymerization, membrane instability and intracellular calcium overload, all of which induce early cell apoptosis [20,22].

Metal-incorporated graphene has generated extensive interest in various biological applications, including biosensing, photothermal therapy, as well as photodynamic therapy [23,24]. Particularly, the photodynamic process quickly produces reactive oxygen species (ROS) comprising hydroxyl radicals, superoxide ions, and singlet oxygen $\left({ }^{1} \mathrm{O}_{2}\right)$, with the latter associated through the main relevant agent of cellular destruction in the photodynamic practice $[10,25]$. Numerous methodologies have been offered to increase the effectiveness of photodynamic therapy (PDT). Occasionally, PDT adequacy was observed when nanoparticles were connected as Photosensitizers (PS) transporters, proposing that the utilization of nanoparticles can overcome the previously mentioned restrictions [14,25-27]. Among the different nanoparticles accessible, for instance quantum dots, nanotubes, liposomal vehicles, 
and gold nanoparticles, the latter has pulled in generous consideration on account of their chemical latency, superb optical properties, and nominal biological toxicity [28-30]. Photodynamic therapy (PDT) has been extensively studied for its high capability for medical applications, especially in the treatment of cancer. Hence, considerable attention has been given to fabricating graphene-based nanomaterials that show higher cell apoptosis death via PDT [25,30-32]. Therefore, in our work, we have treated a human breast cancer cell line with graphene oxide-silver (GO-Ag) nanocomposites to analyze their effectiveness using PDT. Besides, the structural and morphological characteristics of GO-Ag nanocomposites were exposed. Furthermore, mechanism of cytotoxicity GO-Ag against human breast cancerous cells was assessed. In addition, nanocomposites induced morphological changes towards MCF-7 cells which were also an integral component of the cellular mechanism relating to its therapeutic effects and cytotoxicity. The nanocomposites were considered concerning their ability to create the singlet oxygen by using chemical trapping process (DPBF; 1, 3-diphenylisobenzofuran). To potentially recommence and support earlier studies, a statistical study based on linear regression is accomplished on the experimental outcomes to help to understand the contrivance of GO-Ag on the tumor cells. Additionally, this study is also useful for the further investigation of graphene-based nanomaterials in nanomedicine and divulges the present development of photodynamic therapy via nanotechnology.

\section{Materials and Methods}

\subsection{GO-Ag Nanocomposites Preparation}

GO was prepared by the modified Hummers method [33]. The GO (1 g) and distilled water $(30 \mathrm{~mL})$ were added to a $500-\mathrm{mL}$ bottle and ultrasonicated for $30 \mathrm{~min}$. After that, $\mathrm{NaSH}(16 \mathrm{~g})$ was added with continuous stirring, and the mixture was sonicated again for $1 \mathrm{~h}$ at $50{ }^{\circ} \mathrm{C}$, then the mixture was maintained under stirring for $15 \mathrm{~h}$ at $60^{\circ} \mathrm{C}$ in order to produce the thiol group on the surface of GO. The obtained product was washed with distilled water $(50 \mathrm{~mL})$ and then sonicated for $20 \mathrm{~min}$. Then, $0.2 \mathrm{M}$ of $\mathrm{AgNO}_{3}$ was added to the thiol-functionalized graphene oxide (GOSH) solution under continuous stirring. The final product was obtained by centrifugation and washed with distilled water, then dried at room temperature overnight.

\subsection{Cell Culturing (MCF-7, Breast Cancer Cell Line)}

MCF-7 cells were process cultured and cultivated in a T-75 flask (Nunc, Wiesbaden, Germany) containing $10 \mathrm{~mL}$ of complete growth medium (Eagle's Minimum Essential medium EMEM $+10 \%$ $(v / v)$ FBS (fetal bovine serum) $+1 \%$ bovine insulin). Furthermore, for appropriate association, the cells were placed for incubation at $37^{\circ} \mathrm{C}$ for $24 \mathrm{~h}$. The MCF-7 cells (breast cancer cells) were sub-cultured twice or thrice in a week, and after, the cells were washed with $0.25 \%(w / v)$ trypsin to attain $76-80 \%$ confluence [21,34].

\subsection{Labeling of MCF-7 Cells}

MCF-7 cells were harvested at a concentration of $1 \times 10^{5}$ cells/well in 96-well plates and incubated. Furthermore, an ascending dose of GO-Ag nanocomposites (10, 20, 40, 60, 80 and $100 \mu \mathrm{g} / \mathrm{mL}$ ) was delivered at $37{ }^{\circ} \mathrm{C}$ for $24 \mathrm{~h}$ having $10 \% \mathrm{FBS}$ and $5 \% \mathrm{CO}_{2}$. The dose arrangement of GO-Ag with increasing concentration ranging from $10-100 \mu \mathrm{g} / \mathrm{mL}$ was placed in $96-$ well plates, while the remaining column was used as the control [34,35].

\subsection{Photodynamic Therapy of MCF-7 Cells}

For photodynamic therapy experiments, in a 96-well microplate, MCF-7 cells (breast cancer cells) were incubated with a GO-Ag concentration of $10-100 \mu \mathrm{g} / \mathrm{mL}$ at $37^{\circ} \mathrm{C}$. Afterward, the cells were exposed for $15 \mathrm{~min}$ at a Laser light of 430-nm blue wavelength, irradiated with $100 \mathrm{~J} / \mathrm{cm}^{2}$. After being further cultured for another $24 \mathrm{~h}$, the relative cell viabilities were then measured by the MTT assay [36]. 


\subsection{In Vitro Cellular Cytotoxicity MTT Assay}

Finally, to assess the cytotoxicity on MCF-7 cells, the MTT (3-(4,5-dimethyl thiazol-2yl)2,5-diphenyl tetrazolium bromide) assay was performed. After incubation, the medium from the wells was removed. Then, $25 \mu \mathrm{L}$ of MTT $(5 \mathrm{mg} / \mathrm{mL})$ were added into each well and again incubated for $4 \mathrm{~h}$. The media was washed away again, and the cells were dispersed in $50 \mu \mathrm{L}$ of DMSO (dimethylsulfoxide) solvent. The absorbance spectra of the samples were measured at a 595-nm wavelength by a microplate reader [37].

\subsection{Reactive Oxygen Species Fluorescence}

Intracellular ROS production was detected using the non-fluorescent compound CMH2DCFDA (Invitrogen Corporation, Carlsbad, CA, USA). The compound crosses the cell membrane and undergoes deactivation by esterases, producing the nonfluorescent $\mathrm{CMH} 2 \mathrm{DCF}$, which reacts with oxygen species inside the cell to produce highly fluorescent dye chloromethyl dihydro dichlorofluorescein (CMDCF). After inactivation of cells in different concentrations of GO-Ag with the recommended light dose, in humidified air with $5 \%$ of $\mathrm{CO}_{2}$ at $37^{\circ} \mathrm{C}$ for $12 \mathrm{~h}$, the cells were washed gently once in Dulbecco's Modification of Eagle's Medium (DMEM). Cells were loaded with $10 \mu \mathrm{M}$ CMH2DCFDA incubated for $30 \mathrm{~min}$ at $37^{\circ} \mathrm{C}$ and protected from light. Thereafter, cells were exposed to a light dose of $100 \mathrm{~J} / \mathrm{cm}^{2}$ for $2 \mathrm{~min}$ to visualize for ROS production [38,39]. After delicate protocol, cells ROS fluorescence was captured with emission detection at $530 \mathrm{~nm}$.

\subsection{Characterization}

The morphology of GO-Ag was ascertained by a field-emission scanning electron microscope (FE-SEM) (Nova ${ }^{\mathrm{TM}}$ NanoSEM 450), transmission Electron Microscopy (JEM-1011, JEOL, Tokyo, Japan), and an atomic force microscope (AFM, Park Systems Co., Suwon, Korea). Energy dispersive X-rays Analysis (EDAX) was performed for the conformation of elemental analysis. UV-Vis spectroscopy was attained by a UV-visible spectrophotometer (Shimadzu, Kyoto Prefecture, Japan, UV-2450). $X$-ray diffraction (XRD) investigation of nanocomposites was achieved on a PANalytical X'Pert-PRO at room temperature and $\mathrm{CuK} \alpha(\lambda=1.54056 \mathrm{~A})$. The average crystallite size was evaluated by using Scherer's formula as mentioned below [40],

$$
\mathrm{D}_{\beta}=0.89 \lambda / \beta \cos \theta
$$

where the incident wavelength of radiation is given by $\lambda$ and the full width half maximum (FWHM) is given by $\beta$.

\subsection{Cell Morphological Analysis}

MCF-7 cells were plated in six-well plates $\left(1 \times 10^{4}\right.$ cells per well $)$ and incubated with the respective GO-Ag composite concentrations for $24 \mathrm{~h}$. Morphological variations were observed to illustrate the disruptions induced by the GO-Ag composite in MCF-7 cells by inverted phase contrast microscopy at $20 \times$ magnification, as shown in Figure 7.

\subsection{Statistical Analysis}

The results are evaluated as the mean \pm standard deviation of three independent experiments. All of the experimental data were compared using Student's $t$-test. A $p$-value less than 0.05 was considered statistically significant using Excel software. Moreover, the parameters employed in this statistical examination using Mathematica software focused on a linear regression equation, which conveys significant evidence, such as the coefficient of determination, the intercept, the slope, the standard deviation and the variance of the slope of the regression line. To assess the performance parameters of the statistical analysis, a mean $(X)$ was defined from seven independent determinations, 
such as the concentration of GO-Ag nanocomposites, for the obtainable data. Different statistical parameters were intended to confirm the experimental outcomes. A graph of GO-Ag alone and with PDT for cell viability and ROS with linear calibration was plotted (concentration: 10-100 $\mu \mathrm{g} / \mathrm{mL}$ ), demonstrating linearity and regression data [32].

\subsection{Exposure of Singlet Oxygen by Chemical Trapping}

1, 3-Diphenylisobenzofuran (DPBF) was employed to achieve the release of singlet oxygen $\left({ }^{1} \mathrm{O}_{2}\right)$ into the solution by the nanocomposites as illustrated in earlier studies [41,42]. An ethanol solution of $3 \mathrm{~mL}$ having $50 \mu \mathrm{M}$ DPBF and $100 \mu \mathrm{g} / \mathrm{mL}$ of the GO, Ag NPs and GO-Ag or Methylene Blue (MB) solution were employed in a quartz cuvette in the dark. The experiments were performed by exposing the samples to sunshine filtered beyond a shortpass infrared filter $(<550 \mathrm{~nm})$. The absorbance of the solution was calculated at $410 \mathrm{~nm}$, every $30 \mathrm{~s}$ for $3 \mathrm{~min}$ with a NanoDrop 2000 (Thermo Fisher Scientific, Waltham, MA, USA). Photobleaching of DPBF instigated the decreased in absorbance and noted in all experiments. The ${ }^{1} \mathrm{O}_{2}$ quantum yield of the GO, Ag NPs, and GO-Ag nanocomposites in the aqueous solution were measured by using $\mathrm{MB}$ as a standard from the following formula:

$$
\Phi_{\Delta}^{b}=\frac{\Phi_{\Delta}^{a}}{I^{a}} I^{b}
$$

$\Phi_{\Delta}^{b}$ describes the ${ }^{1} \mathrm{O}_{2}$ quantum yield of the nanoparticles, $\Phi_{\Delta}^{a}$ is the ${ }^{1} \mathrm{O}_{2}$ quantum yield of $\mathrm{MB}$ that was calculated by using Rose Bengal (RB) as a standard ( $\Phi_{\mathrm{RB}}=0.75 \mathrm{in} \mathrm{H}_{2} \mathrm{O}$ [43]), ' $I^{\mathrm{b}}$ ' is the slope which signifies the time for the reduction in absorption of the DPBF in the existence of the nanocomposites while ' $I^{\mathrm{a}}$ ' is the slope of MB that describes the time for the decrease in absorption of DPBF in the presence of the MB.

\section{Results and Discussion}

Figure 1a explains the X-ray diffraction (XRD) of GO, a broad diffraction peak for GO appeared at $2 \theta=10^{\circ}$, which is attributed to the (001) lattice plane of GO. The interlayer d-spacing corresponding to this peak was calculated $0.93 \mathrm{~nm}$ that acquainted the stacking between the GO nanosheets [16,17]. The XRD patterns in Figure 1b exhibited that GO incorporated with silver Nanoparticles is crystalline in nature with diffraction peaks at $38.1^{\circ}, 44.4^{\circ}, 64.7^{\circ}$ and $77.4^{\circ}$ corresponding lattice planes (111), (200), (220) and (311), respectively, of the cubic structure (JCPDS Card Number 07-0783). Moreover, the peak for GO was disappeared after decoration of Ag NPs, that can be observed in XRD spectra GO incorporated with Ag Nanoparticles. Therefore, the functionalization of the GO surface with the Ag NPs might prevent the graphene sheets from restacking [31,33]. The average crystallite size of deposited Ag nanoparticles was measured by the Scherer's formula using dominant peak (111), determined to be about $28 \mathrm{~nm}$. Scanning electron microscope (SEM) images of GO exposed a thin transparent layer of the GO sheet and a smooth surface with small wrinkles and folded edges, which is consistent with previous reports as seen in Figure 2a [21,31]. GO-Ag displayed the spherical like shinning Ag nanoparticles decorating on the GO sheets, indicating that Ag particles were successfully attached and evenly dispersed on the GO sheets, as seen in Figure 2b. The size distribution of deposited Ag particles on GO was between 30 and $35 \mathrm{~nm}$, which confirms the XRD data. The composition analysis of the GO-Ag nanocomposites from the energy dispersive X-rays Analysis (EDAX) plot of the field-emission scanning electron microscope (FE-SEM) images is shown in Figure 2c. The EDAX interpretations indicated that the required phase of Ag is presented in the samples. Furthermore, The EDAX outcomes confirmed the occurrence of carbon and oxygen with Ag NPs in the GO-Ag nanocomposites. Figure 2d showed the transmission Electron Microscopy (TEM) of the GO incorporated with Ag NPs in which spherical NPs of Ag decorated on the GO sheet of the average size of $43 \mathrm{~nm}$ was seen, that also described the confirmation of the XRD and FE-SEM results. Figure 3 displayed the AFM image of as-prepared GO-Ag on mica. After stacking the Ag NPs, the thickness of GO-Ag increased to about $10 \mathrm{~nm}$, which shows that the Ag NPs were loaded on the surface of the GO sheets, which can be 
observed from the cross-sectional view. The UV-Vis spectrum revealed the absorbance spectra of GO, GO-Ag NPs and Ag NPs alone as shown in Figure 4. The obtained GO exhibited a maximum absorption peak centered at $220 \mathrm{~nm}$ and only Ag NPs is about $440 \mathrm{~nm}$. After incorporation of Ag NPs with GO, the peak of Ag NPs shifted toward the shorter wavelength, this may be due to the surface Plasmon resonance of Ag NPs. [31].
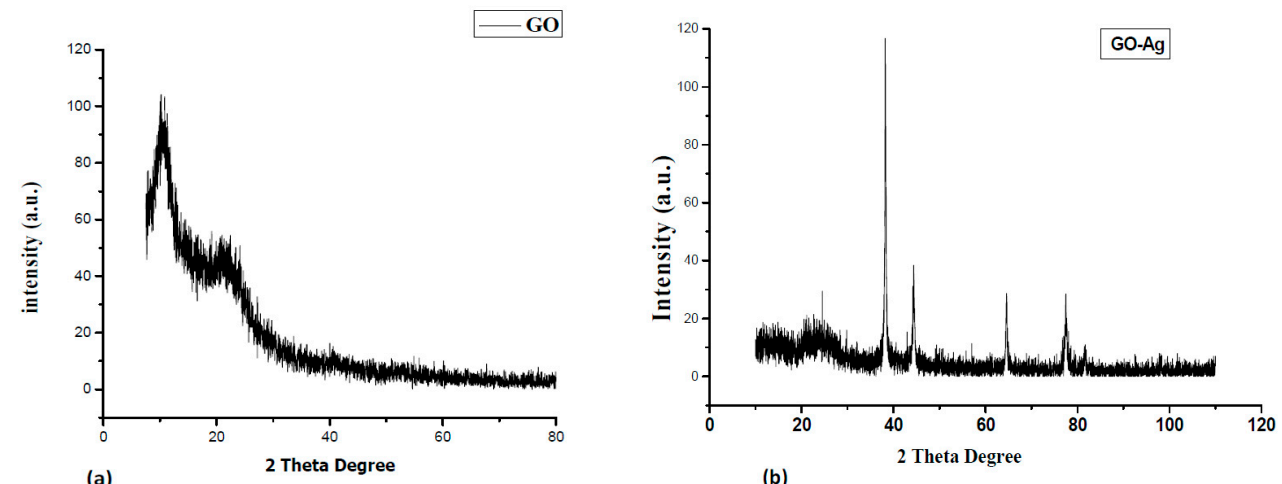

Figure 1. X-Ray diffraction (XRD) structure of (a) Graphene Oxide (GO) (b) Graphene Oxide-silver (GO-Ag) nanocomposites.
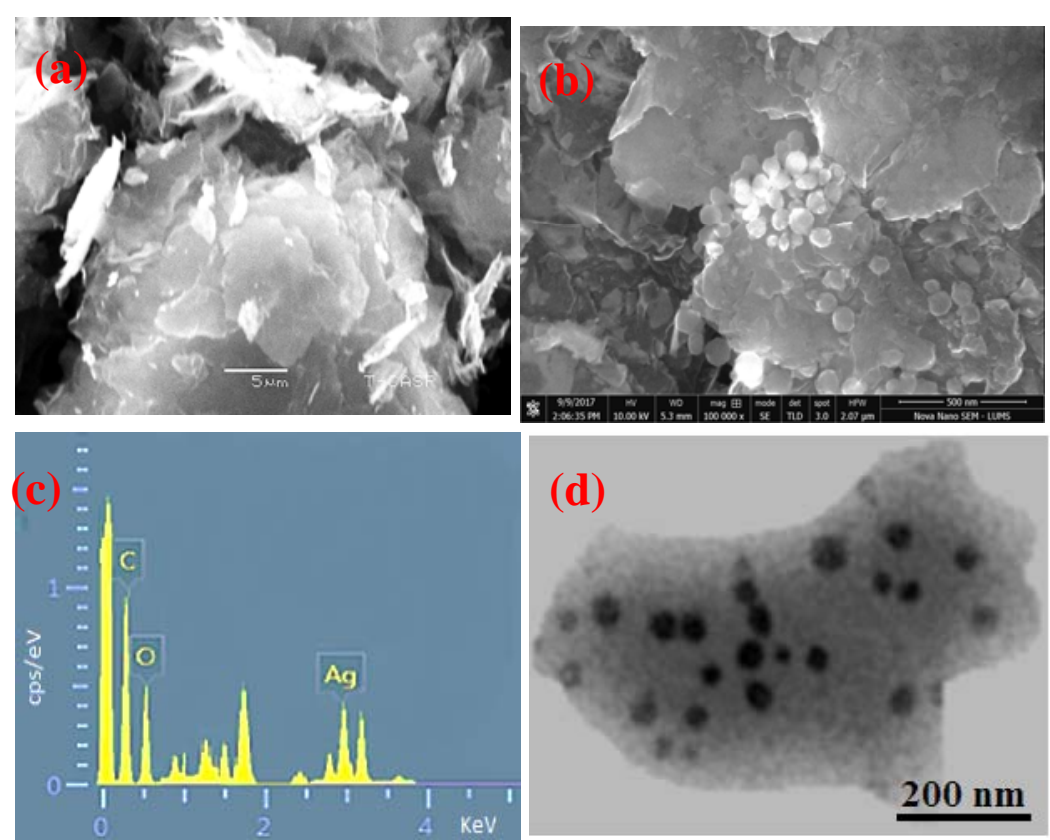

Figure 2. Scanning Electron Microscopy (SEM) analysis of (a) GO (b) GO-Ag nanocomposites (c) Energy Dispersive X-rays (EDAX) analysis of GO-Ag nanocomposites (d) Transmission electron microscopy (TEM) of GO-Ag. 


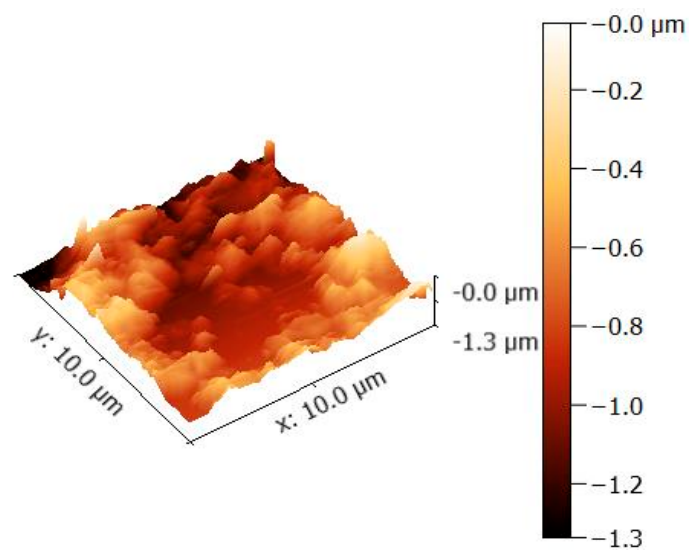

Figure 3. Atomic Force Microscopy (AFM) analysis of GO-Ag nanocomposites.

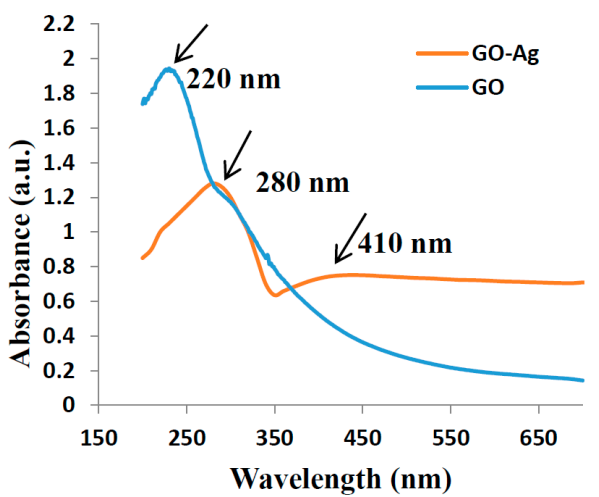

(a)

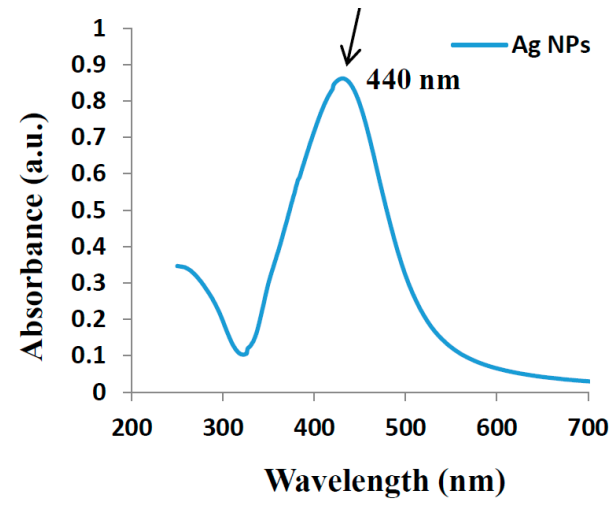

(b)

Figure 4. UV-visible of (a) GO and GO-Ag nanocomposites (b) Ag NPs.

Graphene-based materials have distinctive physicochemical properties and are functional for several prospects. However, their biological properties in organisms will finally determine their destiny in the future. In many recent studies, researchers focused on cell surface adhesion biofilms. Numerous studies have shown that the biofilm phenotype can be described in terms of the genes expressed by biofilm-associated cells. The supramolecular self-assembly approach and their hybrid/complex forms were employed with a laser irradiation mechanism [44-46] for the successful implementation of targeted photothermal and photodynamic efficacy. The promising biomedical uses of graphene/silver nanocomposites have been considered for numerous applications, including antibacterial properties and nanocarriers for controlled stacking on drug delivery conveyance as an anticancer agent $[47,48]$. An organized study was performed to assess the lethality of GO-Ag to MCF-7 cells, a generally-utilized model cell line for toxicological study. The said nano-structural material was employed to decide the likelihood of cell demise because of mechanical stress/cell death. In this work, we attempted to follow the absorbance/optical density measurement by taking different concentrations of GO-Ag as explained in Figure 5 after an uptake time of $24 \mathrm{~h}$. The current experimental study evaluated the optimal density/absorbance of usefulness of GO-Ag in a breast cancer cell line. In addition, it was found that by increasing the concentration of GO-Ag, the mean absorbance/optical density of the stated NPs increased to 0.6 a.u., which is significant, as shown in Figure 5. The results showed the dependency of the significant loss of cell viability and the enormous reactive oxygen species (ROS) liberation under laser light irradiation, which depicted the high profile cancerous cell/tissue injury via cell necrosis/apoptosis, respectively. These outcomes showed that GO-Ag revealed the concentration/dose dependent cytotoxicity with MCF-7 cells. 


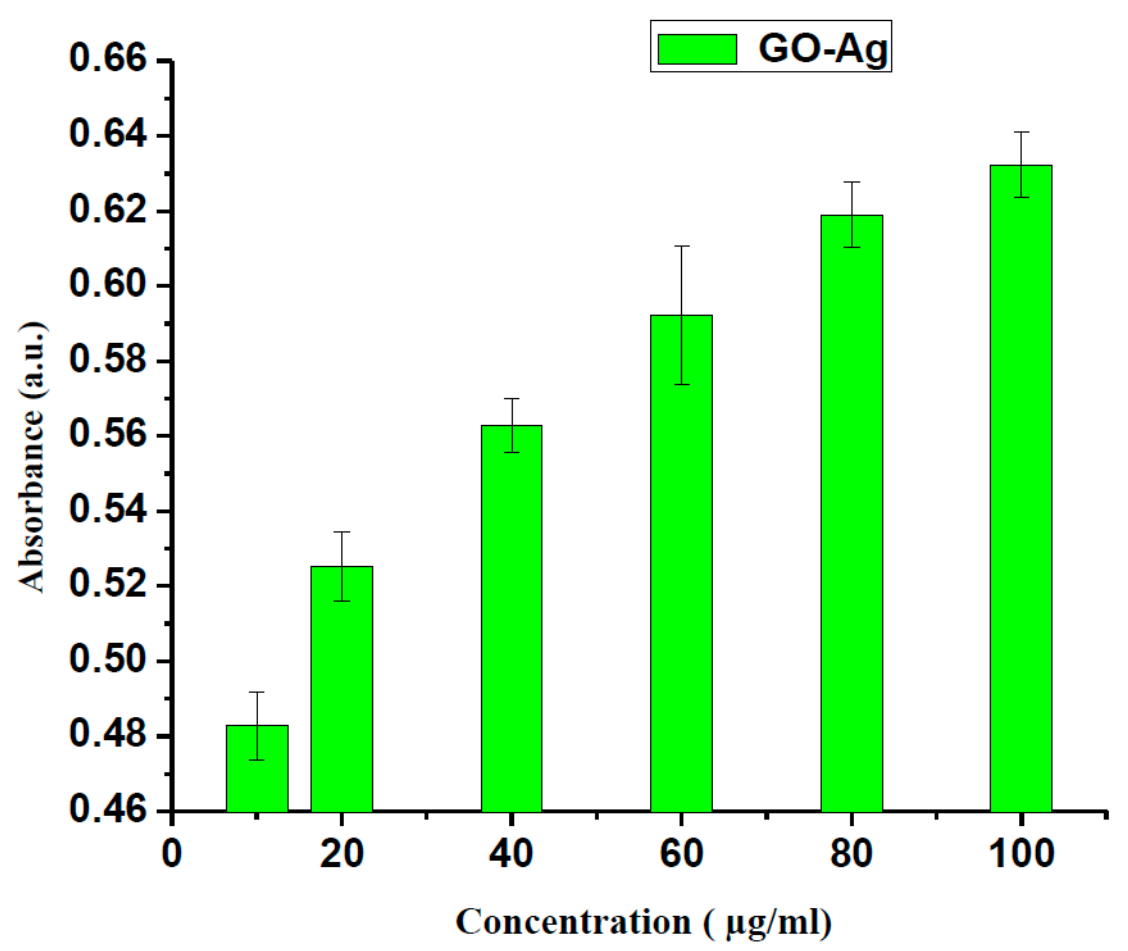

Figure 5. Absorbance versus concentration of GO-Ag nanocomposites.

The cytotoxicity effects of GO-Ag nanocomposites were evaluated using the methyl-thiazoletetrazolium (MTT) assay. In a dose-dependent manner [49], GO showed almost 13\% retained cell viability of MCF-7 cells and cytotoxicity. The fluorinated form of graphene oxide (FGO) showed no toxicity to human breast cancerous cells [50]. The toxicity of graphene-carbon paste (GCP) at four different concentrations (1, 2.5, 5 and $10 \mathrm{wt}$. \%) on MDA-MB-231 breast cancer cells also using the MTT assay was explored by Waiwijit and coworkers [51]. The impact of graphene oxide on the viability using the MTT assay was also investigated by de Marzi et al. with the same cell line. Graphene oxide was used for two different chip sizes $(1.32 \mu \mathrm{m}$ and $130 \mathrm{~nm})$ and a range of concentrations $(10,50$ and $100 \mu \mathrm{g} / \mathrm{mL}$ ). After $24 \mathrm{~h}$ of incubation with both types of $\mathrm{GO}$, the results showed insignificant reduction in the viability of the A549 cells [52]. The toxicity of GO has also been explained in the HBI.F3 human neural stem cell line and BEAS-2B human lung cells. In BEAS-2B cells, the significant concentration and temporal reduction in cell viability were observed at concentrations of 10-100 $\mu \mathrm{g} / \mathrm{mL}$ by the MTT assay, and both early and late apoptosis of cells were improved when compared to the control [53]. HBI.F3 cell viability was decreased with increasing GO nanopellet concentration (25-200 $\mu \mathrm{g} / \mathrm{mL})$, which was verified by the MTT assay and differential pulse voltammetry, a microscopic imaging tool [54]. Breast cancer cells were treated via diverse concentrations $(10-100 \mu \mathrm{g} / \mathrm{mL})$ of GO-Ag for $24 \mathrm{~h}$, as seen in Figure 6, indicating the decrease in cell viability in a dose-dependent manner. The reduction in cell viability was seen to be approximately $44 \%$ at a concentration of $100 \mu \mathrm{g} / \mathrm{mL}$, as shown in Figure $6 \mathrm{a}$, which is significant $(p<0.05, t$-test). Liao et al. [55] established that the cytotoxicity of erythrocytes and skin fibroblasts increased with the concentration of GO. In another study, it was revealed that the cytotoxic effect on HepG2 cells increased as the concentration of GO increased [56]. However, Zhou et al. discussed that GO-Ag reduced the cellular viability of lung cancer cells and hepatocellular carcinoma cells [57]. Nevertheless, previous data have provided evidence that GO-Ag nanocomposites vindicate two simple criteria for a viable anticancer agent, i.e., tumor specificity and nominal toxicity to the normal cells. Moreover, the aforementioned accessible data explained, unambiguously, that the cellular viability loss was in a dose-dependent manner [55,56]. Therefore, the toxicity of GO-Ag to breast cancer cells may also be synergistic, which maximized the interaction among the cells. The toxicity related to the synergistic consequence of GO-Ag nanocomposites with respect to breast cancer cells can include 
disruption of cell wall/membrane and the generation of oxidative stress [58]. In addition, the linearity represents the value of the regression equation analysis $(Y=90.8638-0.5059 X)$ from the calibration data attained $(n=7)$ using GO-Ag cell viability vs. concentration in Figure $6 \mathrm{~b}$. The intercept had a value of 90.8638 with a negative slope of 0.505881 , and the standard error for the slope in regression (Std err $=7.3858)$ was significant. The other parameters included the standard deviation $(S D=19.54)$, the correlation coefficient $\left(r^{2}=0.9385\right)$ with a $p$-value $=4.46 \times 10^{-5}$ and $t$-statistics value $\left(t_{\mathrm{s}}=9.2692\right)$ and $t$-critical value $\left(t_{\text {crit }}=1.943\right)$ showing the significance of results as $t_{\text {crit }}<t_{\mathrm{s}}$. Hence statistical results corroborated the accuracy of the experimental data.

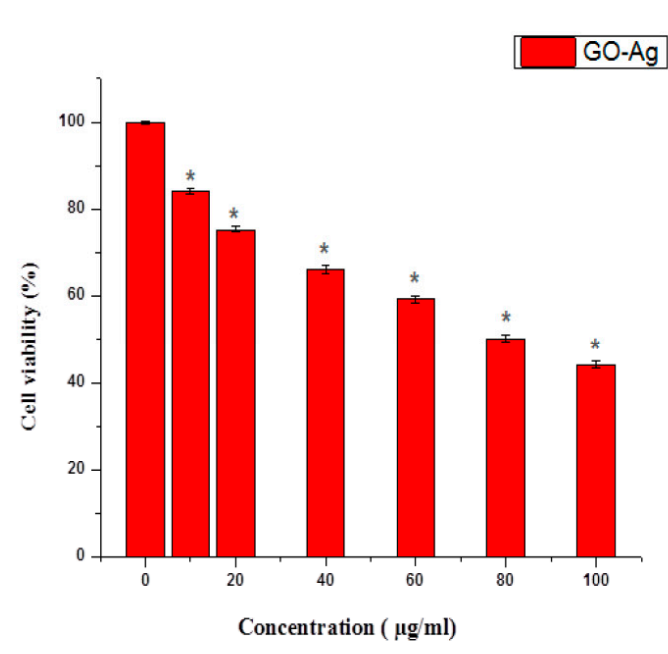

(a)

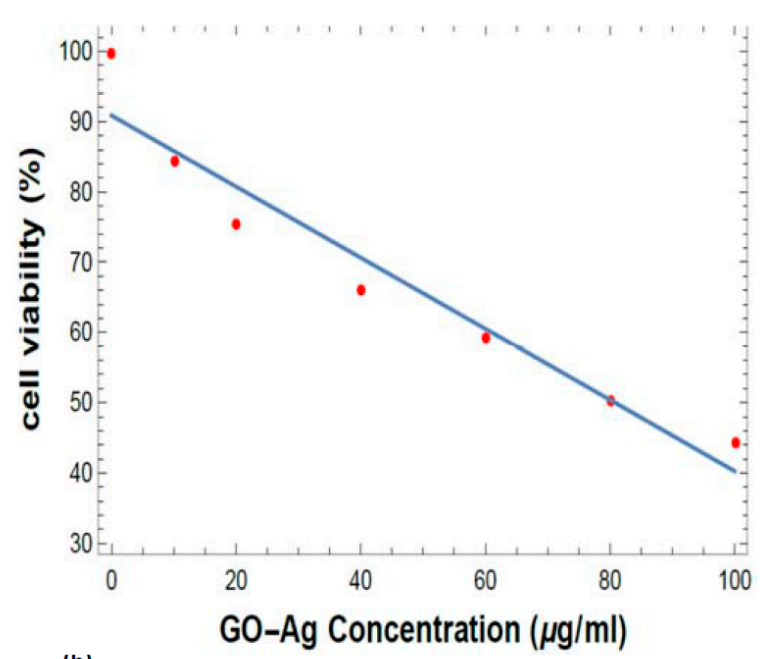

(b)

Figure 6. (a) Loss in cellular viability (\%) in MCF-7 breast cell line treated with GO-Ag nanocomposites after $24 \mathrm{~h}$, $t$-test $\left({ }^{*} p<0.05\right)(\mathbf{b})$ Linear calibration Plot of GO-Ag vs. cell viability.

Previous studies showed that the use of graphene-related derivatives induced apoptosis in cancerous cells. Therefore, we examined whether the addition of the GO-Ag nanocomposite to MCF-7 cultures produced any pronounced effect on the cellular morphology [58]. In addition, to support the results of the cell viability assay, we further evaluated the effect of the GO-Ag nanocomposite on the cell morphology of breast cancer cells. Figure 7 shows a photomicrograph composite of the MCF-7 cells incubated for $24 \mathrm{~h}$ in the presence or absence (control) of GO-Ag nanocomposites. The control MCF-7 cells were appeared as large adherent cells, epithelial and having long arms, with indistinct cell borders. MCF-7 cells when treated with GO-Ag looked different from those of the control group. A reduced number of cells and a significant effect on the cell morphology were observed at different concentrations of GO-Ag, such as 20,40, 80 and $100 \mu \mathrm{g} / \mathrm{mL}$, as seen in Figure 7b-e respectively in the breast cancer cells. At higher concentrations, treated cells appeared as significantly less dense with shrunken arms. Similarly, Jaworski et al. [59] stated the variable toxicity of GO and rGO in glioma cells. In another study, an abridged amount of cells and a noteworthy outcome on the cell morphology were perceived in A2780 cells treated with GO. The GO-treated cells appeared slightly dissimilar from those of the control group [58]. 

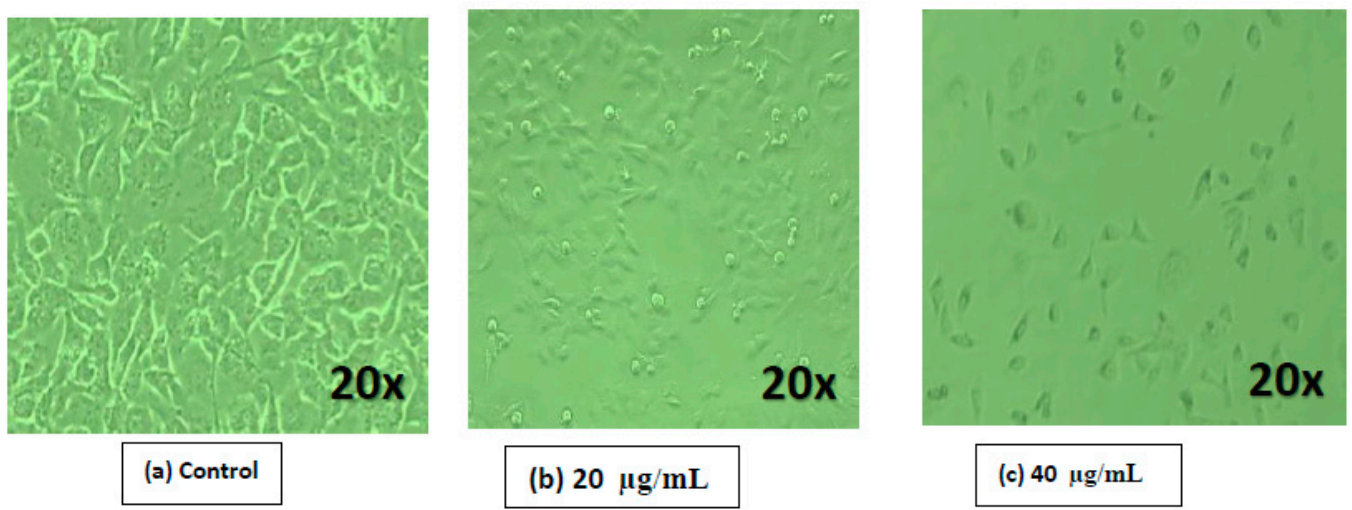

(c) $40 \mu \mathrm{g} / \mathrm{mL}$

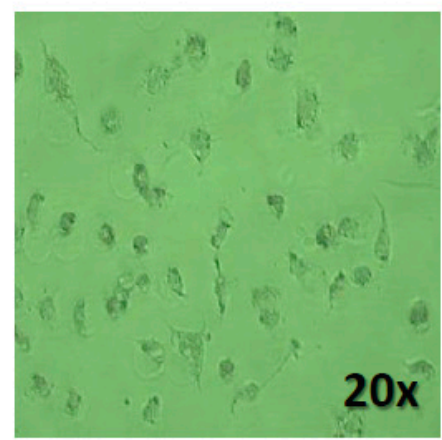

(d) $80 \mu \mathrm{g} / \mathrm{mL}$

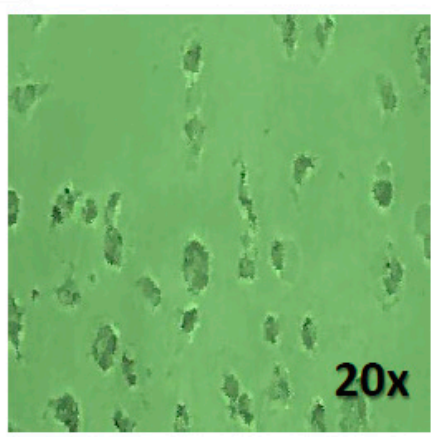

(e) $100 \mu \mathrm{g} / \mathrm{mL}$

Figure 7. Morphological changes of breast cells when treated with GO-Ag. (a) control; (b) $20 \mu \mathrm{g} / \mathrm{mL}$; (c) $40 \mu \mathrm{g} / \mathrm{mL}$; (d) $80 \mu \mathrm{g} / \mathrm{mL}$; (e) $100 \mu \mathrm{g} / \mathrm{mL}$.

Several studies have reported the importance of ROS in cytotoxicity. ROS is one of the proposed toxicological mechanisms of various nanomaterials, including graphene. ROS accumulation is one of the mechanisms for the cell killing effect (cell apoptosis/cell necrosis) [57-59]. In addition, ROS targets the mitochondria, which leads to cell apoptosis (cell death) via vascular blockade $[58,59]$. ROS has the ability to create the oxidative stress that damages the cellular fragments such as cell membranes, DNA, and cellular proteins, which may lead to cell death $[50,55,56]$. Hydroxyl radical $(\mathrm{OH} \cdot)$ is one of the ultimate reactive oxygen radicals that responds quickly through natural molecules originated in viable cells, particularly, lesser density lipoproteins receptors are in majority in the cancerous cells. The incidence of the intracellular ROS was determined by using $2^{\prime}, 7^{\prime}$-dichlorodihydrofluorescein diacetate (H2DCFDA) staining. H2DCFDA is well known cell-permeate indicator for ROS [60]. It is non-fluorescent dye until the acetate groups are removed by intracellular esterase and oxidation occurs within the cell, resulting in a reduced intermediate that can subsequently be oxidized in the presence of ROS and thus fluoresces. Figure 8a-d showed the intracellular ROS generation by fluorescence microscopy image of MCF-7cells. It is perceived that the green fluorescence depicted the presence of intracellular ROS in the cells. Visual effect of (a) control MCF-7 cells (b) GO exposed (c) Ag exposed and (d) GO-Ag exposed to MCF-7 cells were employed. Production of ROS and loss in cellular viability demonstrated the excellent agreement relation towards cell killing effects. These effects/results conclude that GO-Ag interacts with the tissue fluorophores and leads to ROS production resulted cell killing remedy. In addition as long as concentration of GO-Ag increased, ROS fluorescence visualization was also increased. GO-Ag corresponding ROS is dominant over rest of the sample like Ag NPs and GO individually towards tissue. From Figure 8d, it is cleared that MCF-7 cells when treated with GO-Ag are very dominant with significant intensity of fluorescence as compared to GO and Ag NPs alone as seen in Figure 8b,c. 
In Figure 9, depicted liberation of ROS is directly proportional to $\mathrm{Ag}$ alone and GO-Ag accumulation into biological model, but GO-Ag is more dominant as compare to individual Ag NPs when exposed to the biological cells. These results resembled with perfect agreement with previous published data [61-63], as longer as concentration increased, fluorescence Intensity were also increased. In addition, it is confirmed via manifold techniques that release of singlet oxygen $\left({ }^{1} \mathrm{O}_{2}\right)$ into the solution by the nanoparticles as described previously [57-59]. It was investigated that GO-Ag produced more oxygen stress in the tumorous targeted site due to less metabolic activity as compare to healthy part, in healthy tissue their enzymes stability and routine metabolic activity their immune system act as scavenging tool towards this new developed anticancer agent. Basically oxidative stress can cause of cell killing effect via damage proteins, DNA, and lipids, and is involved which precursor to many diseases. Damage to infected cells caused by oxidative stress is related to increased levels of ROS. During oxidative stress, hydrogen peroxide levels are often increased and catalase levels are decreased inside cells $[53,62]$.

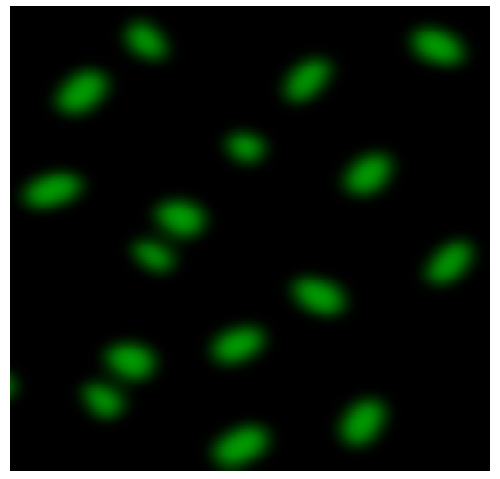

(a)

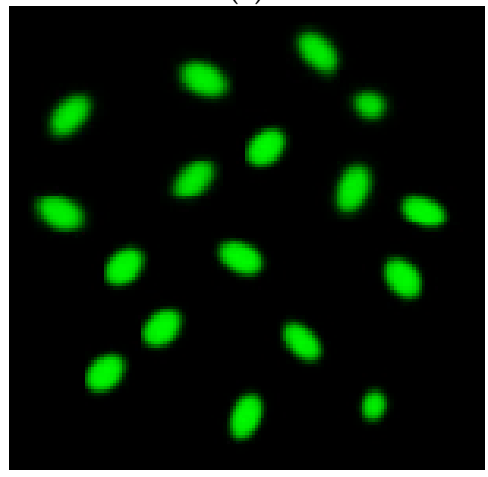

(c)

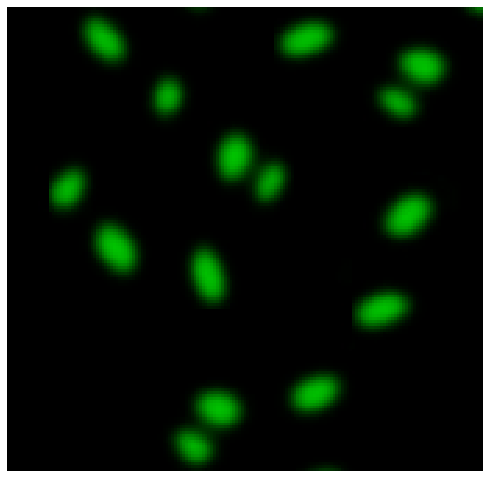

(b)

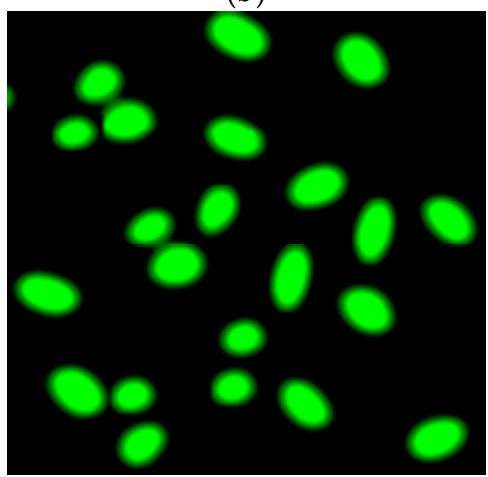

(d)

Figure 8. Qualitative characterization of reactive oxygen species (ROS) formation by H2DCFDA staining using fluorescence microscopy (a) Control MCF-7 cell line; (b) MCF-7 cells treated with GO; (c) MCF-7 cells treated with Ag NPs; and (d) MCF-7 cells treated with GO-Ag nanocomposite.

The release of ${ }^{1} \mathrm{O}_{2}$ into aqueous solution was estimated indirectly by using the DPBF assay. DPBF reacts irreversibly with ${ }^{1} \mathrm{O}_{2}$ causing a decrease in its absorption intensity at $410 \mathrm{~nm}$. The different NPs $(100 \mu \mathrm{g} / \mathrm{mL})$ were mixed in DPBF solution and upon irradiation, absorption was measured over a period of time [41,42]. As shown in Figure 10, Quantum yield of only DPBF had a slight increase in the ${ }^{1} \mathrm{O}_{2}$ production but methylene Blue produced a significant escalation in the ${ }^{1} \mathrm{O}_{2}$ levels. Graphene Oxide too contributed to the significant increase in the ${ }^{1} \mathrm{O}_{2}$ levels but its level was marginally lesser than that of MB. Silver NPs produced the similar induction of ${ }^{1} \mathrm{O}_{2}$ that was significantly higher than graphene oxide alone. For GO-Ag nanocomposites a considerable stronger induction in ${ }^{1} \mathrm{O}_{2}$ production was observed. 


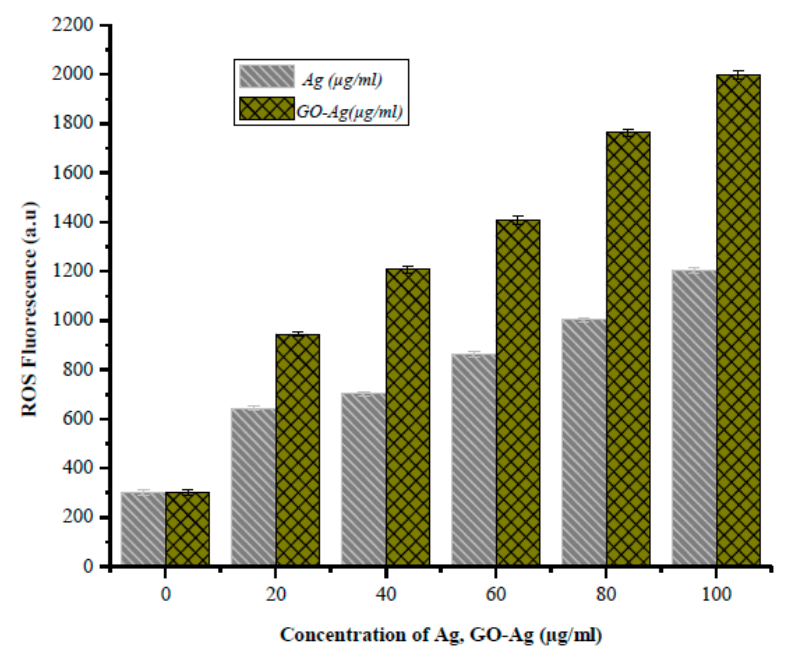

Figure 9. ROS Fluorescence in MCF-7 cells Model after Labeling with Ag NPs and GO-Ag (microgram $/ \mathrm{mL}$ ).

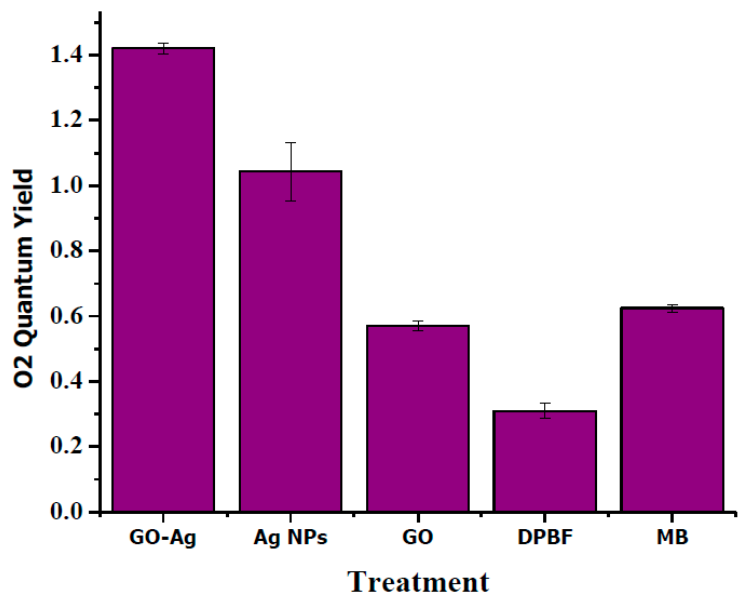

Figure 10. Quantum yield of singlet oxygen of GO-Ag, silver nanoparticles (Ag NPs), GO in comparison to MB.

The PDT technique for cancer detection depended on suitable parameters, e.g., nanoparticle optimal dose and producing the photochemical reaction after irradiation of the proper wavelength of light, which led to cell death. In this study, the possible uptake of GO-Ag was used to trace the photodynamic effects when exposed with a light dose, as shown in Figure 11a. The optimum laser dose of $100 \mathrm{~J} / \mathrm{cm}^{2}$ was selected to check the phototoxicity of GO-Ag concentrations from 10-100 $\mu \mathrm{g} / \mathrm{mL}$, using laser light of blue wavelength (430-nm).Cellular loss up to $20 \%$ was seen and is statistically significant ( $p<0.05, t$-test). In comparison of Figures $6 \mathrm{a}$ and 11a, a significant reduction of cell viability of about $25 \%$ towards MCF-7 cells was observed, which was more under laser irradiation than GO-Ag alone. For the statistical analysis of the results, in Figure 11b, the percent of cell viability after treatment with GO-Ag concentrations is plotted under light irradiation of $100 \mathrm{~J} / \mathrm{cm}^{2}$, showing the linearity using regression equation analysis $(Y=97.8666-0.857 X)$ of the calibration data $(n=7)$. The intercept had a value of 97.8666 with a negative slope of 0.857 , and the standard error for the slope in regression is (Std err $=0.08743$ ). The other parameters included the standard deviation (SD $=27.39155)$, the correlation coefficient $\left(r^{2}=0.9406\right)$ with a $p$-value $=0.00152$ and $t$-statistics value $\left(t_{\mathrm{s}}=6.3251\right)$ and $t$-critical value $\left(t_{\text {crit }}=1.6354\right)$ showing the significance of results as $t_{\text {cri }}<t_{\mathrm{s}}$. Hence statistical results corroborated the accuracy of the experimental data. In recent studies, it was shown that photodynamic therapy can generate ROS and produce mitochondrial destruction, which led 
to apoptotic/necrosis $[64,65]$. Hybrid GO/TiO2 induced the apoptotic response and had excellent photodynamic activity [66] when exposed to a light dose of $48.6 \mathrm{~J} / \mathrm{cm}^{2}$. In another study, a laser of a 671-nm wavelength reduced the cellular viability using photosensitizer chlorin e6 (Ce6) and rGO-PVP-Ce6 at diverse concentrations for $24 \mathrm{~h}$ at room temperature [21].

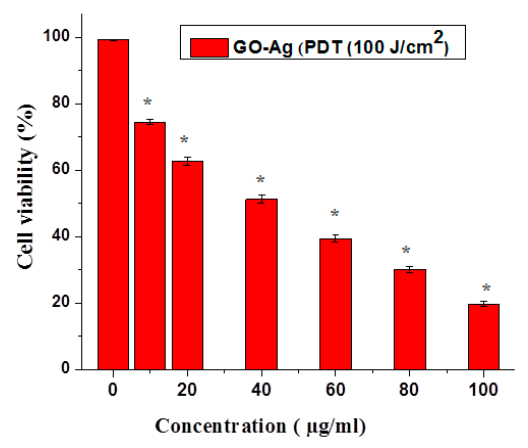

(a)

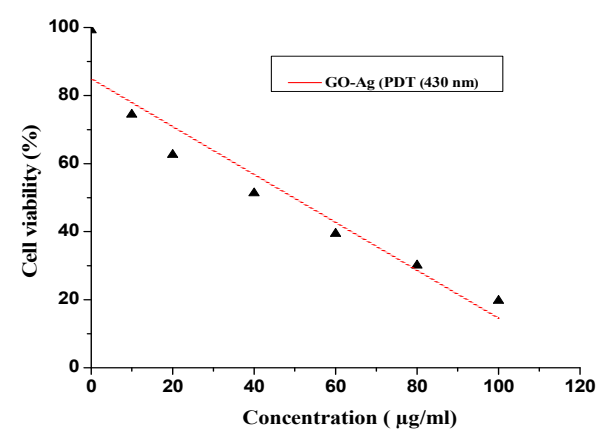

(b)

Figure 11. (a) Cellular viability of GO-Ag treated breast cell carcinoma using PDT $\left(100 \mathrm{~J} / \mathrm{cm}^{2}\right), t$-test $\left({ }^{*} p<0.05\right)$; (b) Linear calibration Plot of GO-Ag vs. cell viability under PDT $\left(100 \mathrm{~J} / \mathrm{cm}^{2}\right)$.

Kolarova et al. demonstrated that ROS overproduction can cause severe cell damage, which leads to cell death, and they made this statement after the investigation of the synergistic mechanism between sonodynamic therapy (SDT) and PDT by using MCF-7cells as an in vitro model [67]. To investigate the effect of the GO-Ag nanocomposite of different concentrations (10-100 $\mu \mathrm{g} / \mathrm{mL})$ on ROS generation under light irradiation of $430 \mathrm{~nm}$, the results clearly indicated that GO-Ag profoundly exaggerated ROS generation when compared to control. It is clearly observed in Figure 12a, a significant rise in the fluorescence of ROS production was observed under laser irradiation parameters and is statistically significant ( $p<0.05, t$-test). The statistical analysis for ROS generation after treatment with GO-Ag concentrations was plotted under light irradiation of $100 \mathrm{~J} / \mathrm{cm}^{2}$, showing the linearity using regression equation analysis $(Y=342.65+19.677 X)$ of the calibration data $(n=7)$ as seen in Figure $12 \mathrm{~b}$. The intercept had a value of 342.65 with a positive slope of 19.677 , and the standard error for the slope in regression is (Std err $=278.4517)$. The other parameters included the standard deviation $(\mathrm{SD}=662.4739)$, the correlation coefficient $\left(r^{2}=0.9357\right)$ with a $p$-value $=0.0025$ and $t$-statistics value $\left(t_{\mathrm{s}}=4.2764\right)$ and $t$-critical value $\left(t_{\text {crit }}=1.942\right)$ showing the significance of results as $t_{\text {crit }}<t_{\mathrm{s}}$. Hence statistical results corroborated the accuracy of the experimental data.

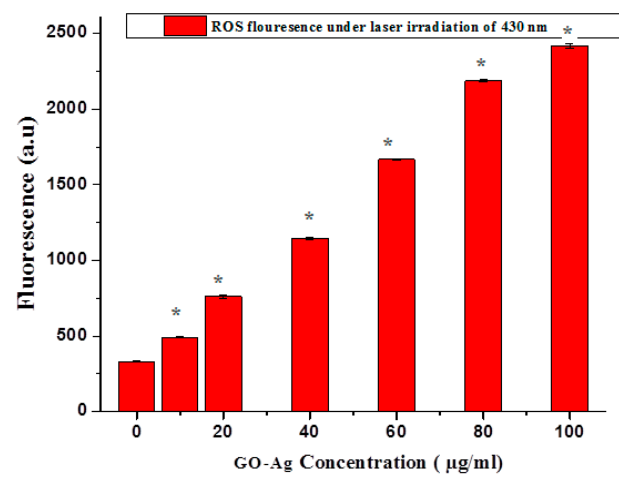

(a)

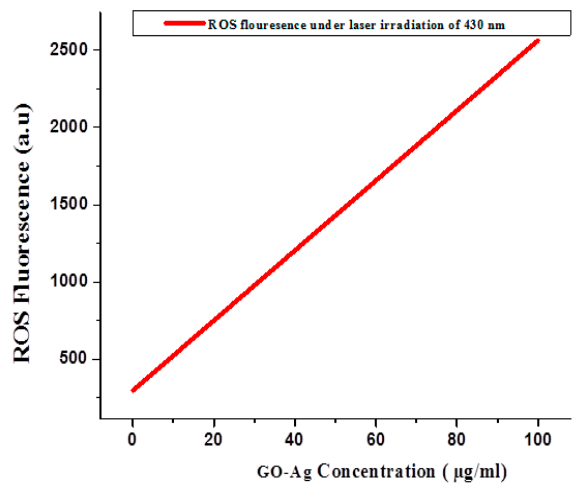

(b)

Figure 12. (a) ROS generation under light irradiation of suitable wavelength (430 nm), $t$-test $(* p<0.05)$; (b) Linear calibration Plot of GO-Ag concentrationvs. ROS fluorescence under PDT $\left(100 \mathrm{~J} / \mathrm{cm}^{2}\right)$. 
The present study exhibited that GO-Ag under a suitable wavelength of light exposure not only liberated reactive oxygen species (ROS), but also arrested the cell cycle by the inhibition MCF-7 cells proliferation through encouraging oxidative stress, which would be valuable for developing highly operative graphene-related aggregates for use in biomedicine $[58,63,64]$. Its schematic diagram is presented below in Figure 13.

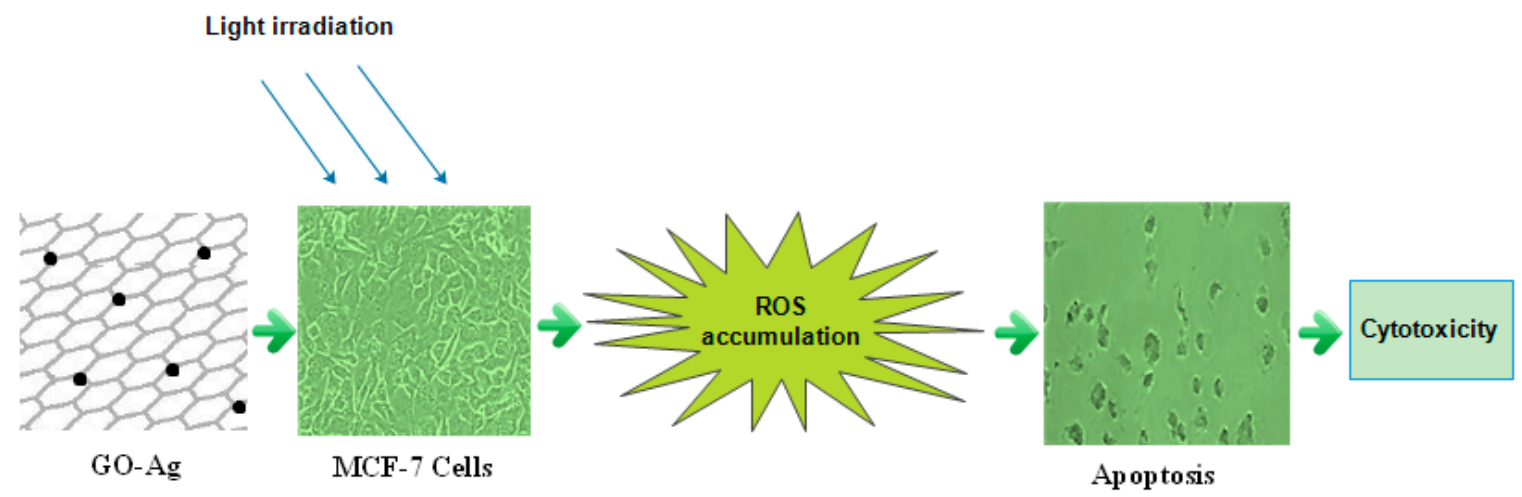

Figure 13. Schematic diagram represented the ROS accumulation by GO-Ag under light irradiation of $430 \mathrm{~nm}$.

In summary, this study evaluated the cytotoxicity and photodynamic effectiveness of GO-Ag nanocomposites towards MCF cells. The reduction of cell viability and the ROS induced by the GO-Ag under light irradiation suggested a synergistic effect. To the best of our knowledge, this is the first report concerning the phototoxicity of graphene oxide-silver nanocomposites to breast cancer cells that also examined the nanocomposite's permanence. Despite the uniqueness of this work, further effort is still required to improve knowledge of the phototoxicity mechanisms produced by graphene-metal-based nanocomposites.

\section{Conclusions}

In this experimental study, GO-Ag was prepared using a hydrothermal method and characterized by applying diverse techniques, such as AFM, SEM, XRD analysis and UV-Vis spectroscopy. Cellular uptake measurements and cytotoxic evaluations were performed using an MTT assay, cell morphological analysis and laser exposure $\left(100 \mathrm{~J} / \mathrm{cm}^{2}\right)$. Cellular loss was also confirmed by inverted microscopy at various concentrations that showed that GO-Ag produced significant toxic effects in MCF-7. GO-Ag exhibited significant cytotoxic differences after the laser exposure and revealed apoptotic activity against a breast cancer cell line. Significant loss of cell viability (up to 65\% under light exposure) exposed the dependency of ROS liberation and prominent cancer cell/tissue damage via cell necrosis/apoptosis (by inducing oxidative stress). The combined effect of GO-Ag with photodynamic therapy in our study generated a synergistic outcome, which revealed that the combined process effectiveness was higher than the individual efficacies of the nanocomposites. To potentially recommence and support earlier studies, a statistical study based on linear regression was accomplished on the experimental outcomes to help to understand the effect of GO-Ag nanocomposites on the tumor cells. This considerable photodynamic effect of similar graphene-based photosensitizer encourages future investigations, which could be applied for biomedical applications, specifically cancer therapy. However, advance investigations are essential to clarify the accurate mechanism(s) of graphene-based photosensitizer in delivering their cargo, and to assess them in cancer therapy in vivo.

Acknowledgments: The authors would like to extend their sincere appreciation to the Deanship of Scientific Research at King Saud University for its funding of this research through the Research Group Project No. RGP-VPP-293. 
Author Contributions: Fozia Shaheen, Muhammad Hammad Aziz, Muhammad Atif, Mahvish Fatima and Riaz Ahmad wrote the paper while Muhammad Atif, Muhammad Fakhar-e-Alam, Saqib Anwar, Fatima Zafar analyzed the data. Muhammad Hammad Aziz, Syed Mansoor Ali, Atif Hanif, Mukhtar Ahmed and Ghazanfar Abbas contributed significantly in arranging the manuscript.

Conflicts of Interest: The authors declare no conflict of interest.

\section{References}

1. Stankovich, S.; Dikin, D.A.; Dommett, G.H.; Kohlhaas, K.M.; Zimney, E.J.; Stach, E.A.; Piner, R.D.; Nguyen, S.T.; Ruoff, R.S. Graphene-based composite materials. Nature 2006, 442, 282-286. [CrossRef] [PubMed]

2. Santos, C.M.; Tria, M.C.; Vergara, R.A.; Ahmed, F.; Advincula, R.C.; Rodrigues, D.F. Antimicrobial graphene polymer (PVK-GO) nanocomposite films Chem. Chem. Commun. 2011, 47, 8892-8894. [CrossRef] [PubMed]

3. Singh, V.; Joung, D.; Zhai, L.; Das, S.; Khondaker, S.I.; Seal, S. Graphene-based materials: Past, present and future. Prog. Mater. Sci. 2011, 56, 1178-1271. [CrossRef]

4. Tian, M.; Qu, L.; Zhang, X.; Zhang, K.; Zhu, S.; Guo, X.; Han, G.; Tang, X.; Sun, Y. Enhanced mechanical and thermal properties of regenerated cellulose/graphene composite fibers. Carbohydr. Polym. 2014, 111, 456-462. [CrossRef] [PubMed]

5. Hu, W.; Peng, C.; Luo, W.; Lv, M.; Li, X.; Li, D.; Huang, Q.; Fan, C. Graphene-based antibacterial paper. ACS Nano 2010, 4, 4317-4323. [CrossRef] [PubMed]

6. Yue, L.; Pircheraghi, G.; Monemian, S.A.; Manas-Zloczower, I. Epoxy composites with carbon nanotubes and graphene nanoplatelets-Dispersion and synergy effects. Carbon 2014, 78, 268-278. [CrossRef]

7. Ang, P.K.; Jaiswal, M.; Lim, C.H.Y.X.; Wang, Y.; Sankaran, J.; Li, A.; Lim, C.T.; Wohland, T.; Barbaros, O.; Loh, K.P. A bioelectronic platform using a graphene-lipid bilayer interface. ACS Nano 2010, 4, 7387-7394. [CrossRef] [PubMed]

8. Xu, Z.; Zhang, J.; Shan, M.; Li, Y.; Li, B.; Niu, J.; Zhou, B.; Qian, X. Organosilane-functionalized graphene oxide for enhanced antifouling and mechanical properties of polyvinylidene fluoride ultrafiltration membranes. J. Membr. Sci. 2014, 458, 1-13. [CrossRef]

9. Aziz, A.; Lim, H.N.; Girei, S.H.; Yaacob, M.H.; Mahdi, M.A.; Huang, N.M.; Pandikumar, A. Silver/graphene nanocomposite-modified optical fiber sensor platform for ethanol detection in water medium. Sens. Actuators B Chem. 2015, 206, 119-125.

10. Shi, S.; Yang, K.; Hong, H.; Chen, F.; Valdovinos, H.F.; Goel, S.; Barnhart, T.E.; Liu, Z.; Cai, W. VEGFR targeting leads to significantly enhanced tumor uptake of nanographene oxide in vivo. Biomaterials 2015, 39, 39-46. [CrossRef] [PubMed]

11. Ali-Boucetta, H.; Bitounis, D.; Raveendran-Nair, R.; Servant, A.; Van Den Bossche, J.; Kostarelos, K. Purified graphene oxide dispersions lack in vitro cytotoxicity and in vivo pathogenicity. Adv. Healthc. Mater. 2013, 2, 433-441. [CrossRef] [PubMed]

12. Mendes, R.G.; Koch, B.; Bachmatiuk, A.; Ma, X.; Sanchez, S.; Damm, C.; Schmidt, O.G.; Gemming, T.; Eckert, J.; Rümmeli, M.H. A size dependent evaluation of the cytotoxicity and uptake of nanographene oxide. J. Mater. Chem. B 2015, 3, 2522-2529. [CrossRef]

13. Russier, J.; Treossi, E.; Scarsi, A.; Perrozzi, F.; Dumortier, H.; Ottaviano, L.; Meneghetti, M.; Palermo, V.; Bianco, A. Evidencing the mask effect of graphene oxide: A comparative study on primary human and murine phagocytic cells. Nanoscale 2013, 5, 11234-11247. [CrossRef] [PubMed]

14. Linares, J.; Matesanz, M.C.; Vila, M.; Feito, M.J.; Goncalves, G.; Vallet-Regi, M.; Marques, P.A.; Portolés, M.T. Endocytic mechanisms of graphene oxide nanosheets in osteoblasts, hepatocytes and macrophages. ACS Appl. Mater. Interfaces 2014, 6, 13697-13706. [CrossRef] [PubMed]

15. Wang, K.; Ruan, J.; Song, H.; Zhang, J.; Wo, Y.; Guo, S.; Cui, D. Biocompatibility of Graphene Oxide. Nanoscale Res. Lett. 2011, 6, 8. [CrossRef] [PubMed]

16. Yang, K.; Zhang, S.; Zhang, G. Graphene in mice: Ultrahigh in vivo tumor uptake and efficient photothermal therapy. Nano Lett. 2010, 10, 3318-3323. [CrossRef] [PubMed]

17. Lv, M.; Zhang, Y.; Liang, L. Effect of graphene oxide on undifferentiated and retinoic acid-differentiated SH-SY5Y cells line. Nanoscale 2012, 4, 3861-3866. [CrossRef] [PubMed] 
18. AshaRani, P.V.; Mun, G.L.K.; Hande, M.P.; Valiyaveettil, S. Cytotoxicity and genotoxicity of silver nanoparticles in human cells. ACS Nano 2009, 3, 279-290. [CrossRef] [PubMed]

19. Jun, Y.; Seo, J.; Cheon, J. Nanoscaling laws for magnetic nanoparticles and their applications in biomedical sciences. Acc. Chem. Res. 2008, 41, 179-189. [CrossRef] [PubMed]

20. Xie, J.; Liu, G.; Eden, H.; Ai, H.; Chen, X. Surface-engineered magnetic nanoparticle platforms for cancer imaging and therapy. Acc. Chem. Res. 2011, 44, 883-892. [CrossRef] [PubMed]

21. Gurunathan, S.; Han, J.W.; Eppakayala, V.; Jeyaraj, M.; Kim, J.H. Cytotoxicity of biologically synthesized silver nanoparticles in mda-mb-231 human breast cancer cells. BioMed Res. Int. 2013, 2013, 535796. [CrossRef] [PubMed]

22. Ma, W.R.; Jing, L.; Valladares, A.; Mehta, S.L.; Wang, Z.Z.; Li, P.A.; Bang, J.J. Silver nanoparticle exposure induced mitochondrial stress, caspase- 3 activation and cell death: Amelioration by sodium selenite. Int. J. Biol. Sci. 2015, 11, 860-867. [CrossRef] [PubMed]

23. Zhou, L.; Jiang, H.; Wei, S.; Ge, X.; Zhou, J.; Shen, J. High-efficiency loading of hypocrellin B on graphene oxide for photodynamic therapy. Carbon 2012, 50, 5594-5604. [CrossRef]

24. Tian, B.; Wang, C.; Zhang, S.; Feng, L.; Liu, Z. Photothermally enhanced photodynamic therapy delivered by nano-graphene oxide. ACS Nano 2011, 5, 7000-7009. [CrossRef] [PubMed]

25. Xie, J.; Pan, X.; Wang, M.; Yao, L.; Liang, X.; Ma, J.; Fei, Y.; Wang, P.-N.; Mi, L. Targeting and photodynamic killing of cancer cell by nitrogen-doped titanium dioxide coupled with folic acid. Nanomaterials 2016, 6, 113. [CrossRef] [PubMed]

26. Vivero-Escoto, J.L.; Elnagheeb, M. Mesoporous silica nanoparticles loaded with cisplatin and phthalocyanine for combination chemotherapy and photodynamic therapy in vitro. Nanomaterials 2015, 5, 2302-2316. [CrossRef] [PubMed]

27. Dou, Q.Q.; Teng, C.P.; Ye, E.; Loh, X.J. Effective near-infrared photodynamic therapy assisted by upconversion nanoparticles conjugated with photosensitizers. Int. J. Nanomed. 2015, 10, 419-432.

28. Qiu, H.; Yang, C.; Shao, W.; Damasco, J.; Wang, X.; Ågren, H.; Prasad, P.; Chen, G. Enhanced Upconversion Luminescence in $\mathrm{Yb}^{3+} / \mathrm{Tm}^{3+}$-Codoped Fluoride Active Core/Active Shell/Inert Shell Nanoparticles through Directed Energy Migration. Nanomaterials 2014, 4, 55-68. [CrossRef] [PubMed]

29. Silver, J.; Ou, W. Photoactivation of quantum dot fluorescence following endocytosis. Nano Lett. 2005, 5, 1445-1449. [CrossRef] [PubMed]

30. Huang, X.; Tian, X.-J.; Yang, W.-L.; Ehrenberg, B.; Chen, J.-Y. The conjugates of gold nanorods and chlorin e6 for enhancing the fluorescence detection and photodynamic therapy of cancers. Phys. Chem. Chem. Phys. 2013, 15, 15727-15733. [CrossRef] [PubMed]

31. Al-Marri, A.H.; Khan, M.; Khan, M. Pulicaria glutinosa extract: A toolbox to synthesize highly reduced graphene oxide-silver nanocomposites. Int. J. Mol. Sci. 2015, 16, 1131-1142. [CrossRef] [PubMed]

32. Aziz, M.H.; Fakhar-E-Alam, M.; Fatima, M.; Shaheen, F.; Iqbal, S.; Atif, M. Photodynamic Effect of Ni Nanotubes on an HeLa Cell Line. PLoS ONE 2016, 11, e0150295. [CrossRef]

33. Hummers, W.S.; Offeman, R.E. Preparation of graphtic oxide. J. Am. Chem. Soc. 1958, 80, 1339. [CrossRef]

34. Fatima, M.; Fakhar-E-Alam, M.; Atif, M.; Zaidi, S.S.Z.; Suleman, R.; Shakoor, M.N. Apoptotic effect of $\alpha-\mathrm{Fe}_{2} \mathrm{O}_{3}$ and $\mathrm{SiO}_{2}$ nanoparticles in human rhabdomyosarcoma cell line. Laser Phys. 2014, 24, 125602. [CrossRef]

35. Atif, M.; Firdous, S.; Khurshid, A.; Noreen, L.; Zaidi, S.S.Z.; Ikram, M. In vitro study of 5-aminolevulinic acid-based photodynamic therapy for apoptosis in human cervical HeLa cell line. Laser Phys. Lett. 2009, 6, 886. [CrossRef]

36. Hayashida, Y.; Ikeda, Y.; Sawada, K.; Kawai, K.; Kato, T.; Kakehi, Y.; Araki, N. Invention of a novel photodynamic therapy for tumors using a photosensitizing PI3K inhibitor. Int. J. Cancer 2016, 139, 700-711. [CrossRef] [PubMed]

37. Berridge, M.V.; Tan, A.S. Characterization of the cellular reduction of 3-(4,5-dimethylthiazol-2-yl)-2,5diphenyltetrazolium bromide (MTT): Subcellular localization, substrate dependence, and involvement of mitochondrial electron transport in MTT reduction. Arch. Biochem. Biophys. 1993, 303, 474-482. [CrossRef] [PubMed]

38. Fakhar-e-Alam, M.; Kishwar, S.; Khan, Y.; Siddique, M.; Atif, M.; Nur, O. Tumoricidal effects of nanomaterials in HeLa cell line. Laser Phys. 2011, 21, 1978-1988. [CrossRef] 
39. Fakhar-e-Alam, M.; Kishwar, S.; Siddique, M.; Nur, O.; Willander, M. The photodynamic effect of ZnO nanorods and their ligands with different photosensitizers. Rev. Nanosci. Nanotechnol. 2012, 1, 40-51. [CrossRef]

40. Morais, V.K.; Garg, A.C.; Oliveira, L.P.; Silva, R.B.; Azevedo, A.M.L.; Silva, E.C.D. Lima, Synthesis and characterization of size-controlled cobalt-ferrite-based ionic ferrofluids. J. Magn. Magn. Mater. 2001, 225, 37-40. [CrossRef]

41. Arooj, S.; Nazir, S.; Nadhman, A.; Ahmad, N.; Muhammad, B.; Ahmad, I.; Mazhar, K.; Abbasi, R. Novel $\mathrm{ZnO}:$ Ag nanocomposites induce significant oxidative stress in human fibroblast malignant melanoma (Ht144) cells. Beilstein J. Nanotechnol. 2015, 6, 570-582. [CrossRef] [PubMed]

42. Xiao, L.; Gu, L.; Howell, S.B.; Sailor, M.J. Porous Silicon Nanoparticle Photosensitizers for Singlet Oxygen and Their Phototoxicity against Cancer Cells. ACS Nano 2011, 5, 3651-3659. [CrossRef] [PubMed]

43. Redmond, R.W.; Gamlin, J.N. A Compilation of Singlet Oxygen Yields from Biologically Relevant Molecules. Photochem. Photobiol. 1999, 70, 391-475. [CrossRef] [PubMed]

44. Cui, J.; Yang, Y.; Zheng, M.; Liu, Y.; Xiao, Y.; Lei, B.; Chen, W. Facile fabrication of graphene oxide loaded with silver nanoparticles as antifungal materials. Mater. Res. Express 2014, 1, 045007. [CrossRef]

45. Huang, X.; Jain, P.K.; El-Sayed, I.H.; El-Sayed, M.A. Plasmonic photothermal therapy (PPTT) using gold nanoparticles. Lasers Med. Sci. 2008, 23, 217-228. [CrossRef] [PubMed]

46. Hu, K.W.; Liu, T.M.; Chung, K.Y.; Huang, K.S.; Hsieh, C.T.; Sun, C.K.; Yeh, C.S. Efficient near-IR hyperthermia and intense nonlinear optical imaging contrast on the gold nanorod-in-shell nanostructures. J. Am. Chem. Soc. 2009, 40, 14186-14187. [CrossRef] [PubMed]

47. Skrabalak, S.E.; Chen, J.; Sun, Y.; Lu, X. Gold Nanocages: Synthesis, Properties, and Applications. Acc. Chem. Res. 2008, 12, 1587-1595. [CrossRef] [PubMed]

48. Markovic, Z.M.; Harhaji-Trajkovic, L.M.; Todorovic-Markovic, B.M. In vitro comparison of the photothermal anticancer activity of graphene nanoparticles and carbon nanotubes. Biomaterials 2011, 32, 1121-1129. [CrossRef] [PubMed]

49. Chaudhari, N.S.; Pandey, A.P.; Patil, P.O.; Tekade, A.R.; Bari, S.B.; Deshmukh, P.K. Graphene oxide based magnetic nanocomposites for efficient treatment of breast cancer. Mater. Sci. Eng. C 2014, 37, $278-285$. [CrossRef] [PubMed]

50. Romero-Aburto, R.; Narayanan, T.N.; Nagaoka, Y.; Hasumura, T.; Mitcham, T.M.; Fukuda, T.; Cox, P.J.; Bouchard, R.R.; Maekawa, T.; Sakthi Kumar, D.; et al. Fluorinated graphene oxide; a new multimodal material for biological applications. Adv. Mater. 2013, 25, 5632-5637. [CrossRef] [PubMed]

51. Waiwijit, U.; Kandhavivorn, W.; Oonkhanond, B.; Lomas, T.; Phokaratkul, D.; Wisitsoraat, A.; Tuantranont, A. Cytotoxicity assessment of MDA-MB-231 breast cancer cells on screen-printed graphene-carbon paste substrate. Colloids Surf. B Biointerfaces 2014, 113, 190-197. [CrossRef] [PubMed]

52. De Marzi, L.; Ottaviano, L.; Perrozzi, F.; Nardone, M.; Santucci, S.; De Lapuente, J.; Borras, M.; Treossi, E.; Palermo, V.; Poma, A. Flake size-dependent cyto and genotoxic evaluation of graphene oxide on in vitro A549, $\mathrm{CaCo}_{2}$ and vero cell lines. J. Biol. Regul. Homeost. Agents 2014, 28, 281-289. [PubMed]

53. Vallabani, N.V.; Mittal, S.; Shukla, R.K.; Pandey, A.K.; Dhakate, S.R.; Pasricha, R.; Dhawan, A. Toxicity of graphene in normal human lung cells (BEAS-2B). J. Biomed. Nanotechnol. 2011, 7, 106-107. [CrossRef] [PubMed]

54. Kang, S.M.; Kim, T.H.; Choi, J.W. Cell chip to detect effects of graphene oxide nanopellet on human neural stem cell. J. Nanosci. Nanotechnol. 2012, 12, 5185-5190. [CrossRef] [PubMed]

55. Liao, K.H.; Lin, Y.S.; Macosko, C.W.; Haynes, C. Cytotoxicity of graphene oxide and graphene in human erythrocytes and skin fibroblasts. ACS Appl. Mater. Interfaces 2011, 3, 2607-2615. [CrossRef] [PubMed]

56. Lammel, T.; Boisseaux, P.; Fernández-Cruz, M.L.; Navas, J.M. Internalization and cytotoxicity of graphene oxide and carboxyl graphenenanoplatelets in the human hepatocellular carcinoma cell line Hep G2. Part. Fibre Toxicol. 2013, 10, 27. [CrossRef] [PubMed]

57. Zhou, X.Y.; Dorn, M.; Vogt, J.; Spemann, D.; Yu, W.; Mao, Z.W. A quantitative study of the intracellular concentration of graphene/noble metal nanoparticle composites and their cytotoxicity. Nanoscale 2014, 6, 8535-8542. [CrossRef] [PubMed]

58. Gurunathan, S.; Han, J.W.; Park, J.H. Reduced graphene oxide-silver nanoparticle nanocomposite: A potential anticancer nanotherapy. Int. J. Nanomed. 2015, 10, 6257-6276. [CrossRef] [PubMed] 
59. Jaworski, S.; Sawosz, E.; Grodzik, M.; Winnicka, A.; Prasek, M.; Wierzbicki, M.; Chwalibog, A. In vitro evaluation of the effects of graphene platelets on glioblastoma multiforme cells. Int. J. Nanomed. 2013, 8, 413-420.

60. Wu, D.; Yotnda, P. Production and Detection of Reactive Oxygen Species (ROS) in Cancers. J. Vis. Exp. 2011, 57, 3357. [CrossRef] [PubMed]

61. Zhang, W.; Yan, L.; Li, M.; Zhao, R.; Yang, X.; Ji, T.; Gu, Z.; Yin, J.J.; Gao, X.; Nie, G. Deciphering the underlying mechanisms of oxidation-state dependent cytotoxicity of graphene oxide on mammalian cells. Toxicol. Lett. 2015, 237, 61-71. [CrossRef] [PubMed]

62. Hu, X.; Ouyang, S.; Mu, L.; An, J.; Zhou, Q. Effects of graphene oxide and oxidized carbon nanotubes on the cellular division, microstructure, uptake, oxidative stress, and metabolic profiles. Environ. Sci. Technol. 2015, 49, 10825-10833. [CrossRef] [PubMed]

63. Liu, S.; Zeng, T.H.; Hofmann, M.; Burcombe, E.; Weim, J.; Jiang, R.; Kong, J.; Chen, Y. Antibacterial activity of graphite, graphite oxide, graphene oxide, and reduced graphene oxide: Membrane and oxidative stress. ACS Nano 2011, 5, 6971-6980. [CrossRef] [PubMed]

64. Li, Y.; Dong, H.; Li, Y.; Shi, D. Graphene-based nanovehicles for photodynamic medical therapy. Int. J. Nanomed. 2015, 10, 2451-2459.

65. Dong, H.Q.; Zhao, Z.; Wen, H.; Li, Y.; Guo, F.; Shen, A.; Pilger, F.; Lin, C.; Shi, D. Poly(ethylene glycol) conjugated nano-graphene oxide for photodynamic therapy. Sci. China Chem. 2010, 53, 2265-2271. [CrossRef]

66. Hu, Z.; Huang, Y.D.; Sun, S.F.; Guan, W.C.; Yao, Y.H.; Tang, P.Y. Visible light driven photodynamic anticancer activity of graphene oxide/ $\mathrm{TiO}_{2}$ hybrid. Carbon 2012, 50, 994-1004. [CrossRef]

67. Kolarova, H.; Nevrelova, P.; Tomankova, K.; Kolar, P.; Bajgar, R.; Mosinger, J. Production of reactive oxygen species after photodynamic therapy by porphyrin sensitizers. Gen. Physiol. Biophys. 2008, 27, 101. [PubMed]

(C) 2017 by the authors. Licensee MDPI, Basel, Switzerland. This article is an open access article distributed under the terms and conditions of the Creative Commons Attribution (CC BY) license (http:/ / creativecommons.org/licenses/by/4.0/). 